\title{
STUDIES OF A MYXOVIRUS RECOVERED FROM PATIENTS WITH INFECTIOUS HEPATITIS
}

\author{
I. Isolation AND Characterization* \\ By HARVEY LIEBHABER, $\ddagger$ \& M.D., SAUL KRUGMAN, M.D., DOROTHY \\ MCGREGOR, AND JOAN P. GILES, $\|$ M.D. \\ (From the Department of Pediatrics, New York University School of Medicine, \\ and The Willowbrook State School, Staten Island, New York) \\ Plates 66 to 68 \\ (Received for publication, August 3, 1965)
}

Many investigators have attempted to isolate and propagate the virus of infectious hepatitis in laboratory animals, embryonated eggs, and a variety of tissue cultures (1-6). Though many initial reports of these studies were encouraging, attempts to repeat or extend the original observations have failed.

The natural history of infectious hepatitis has been studied in detail at the Willowbrook State School (7-9). During the course of these studies, serial specimens of blood, urine, and feces were collected from human subjects during the incubation period, acute, and convalescent phases of experimentally induced, as well as naturally acquired, infectious hepatitis.

This report describes the properties of serologically identical myxoviruses recovered from two urine specimens and eight serum specimens obtained from 4 patients during the incubation period of infectious hepatitis.

A preliminary report describing the early findings made in this study has recently been published (10).

\section{Materials and Methods}

Tissue Culture.-Roller tube cultures of diploid human embryonic lung fibroblasts (WI-38) were either purchased ${ }^{1}$ or prepared in this laboratory from stock cultures at the 25 th to 30 th

* This investigation was supported in part by Public Health Service Research Grant AI 05148-02 from the National Institute of Allergy and Infectious Diseases, and in part by the Health Research Council of the City of New York under Contract No. U-1056 and was carried out under the sponsorship of the Commission on Viral Infections, Armed Forces Epidemiological Board and was supported in part by the Office of the Surgeon General, United States Army Medical Research and Development Command.

$\ddagger$ Recipient of Public Health Service Research Career Development Award 5-K3-AI-16726-02 from the National Institute of Allergy and Infectious Diseases.

\$ Present address: Yale University School of Medicine, New Haven, Connecticut.

|| Career Scientist of the Health Research Council of the City of New York.

${ }^{1}$ Microbiological Associates, Bethesda, Maryland. 
passage level. ${ }^{2}$ Stock cultures of HeLa cells and a continuous line of African green monkey kidney cells designated as WGM- $1^{3}$ were used to prepare roller tube and/or monolayer cultures in $60 \mathrm{~mm}$ Petri dishes. Primary cultures of human embryonic kidney (HEK) cells were prepared in this laboratory.

Cultures were grown in Eagles minimal essential medium (MEM) (11) containing antibiotics and 10 per cent agammaglobulinemic calf serum (MEM-10 CS), and maintained in MEM containing 2 per cent agammaglobulinemic calf serum (MEM-2CS).

Specimens for Virus Isolation.-Serum and urine collected from patients with experimentally induced or naturally acquired infectious hepatitis were stored frozen at $-65^{\circ} \mathrm{C}$ for periods ranging from several weeks to 3 years. Undiluted specimen was inoculated into each of 3 to 5 WI-38 roller tube cultures. Nutrient fluids were changed every 4 or 5 days. If cytopathic changes (CPE) were not observed by the 10th day, the cells were harvested in the tissue culture fluid and inoculated into fresh cultures. This procedure was continued until CPE appeared or through 6 blind passages at which point the specimen was considered to be negative.

Infectivity Titrations and Neutralization Tests in Tissue Cullure Roller Tubes.-Titration of infectivity was performed by inoculating $0.1 \mathrm{ml}$ of serial 10-fold or 3-fold dilutions of the test suspension into each of 5 roller tube cultures. The cultures were observed for CPE or tested on the 7th day for the presence of virus by the technique of hemadsorption with 0.5 per cent guinea pig erythrocytes (12). Infectivity titers were calculated by the method of Reed and Muench (13). In the neutralization test, serial 2-fold dilutions of a test serum mixed with an equal volume of virus suspension estimated to contain 100 to $1000 \mathrm{TCID}_{50}$ of virus were incubated for 30 minutes at $37^{\circ} \mathrm{C}$, and then inoculated in $0.2 \mathrm{ml}$ volumes into each of 5 roller tube cultures. Simultaneous titration of the virus employed was included in every neutralization test. When the presence of infective virus was determined by the development of CPE, the test was concluded 48 hours after the appearance of CPE in non-neutralized virus control tubes. When hemadsorption was used as an index of infectivity, the final readings were made 7 days after inoculation. The neutralization titer of the serum was taken as the reciprocal of the highest serum dilution which completely neutralized infectivity.

Infectivity Titrations and Neutralization Tests by the Plaque Method.-The plaque assay for infectivity was carried out on WGM-1 monolayers according to the method described (14). The overlay medium consisted of equal parts of double strength MEM containing 10 per cent inactivated calf serum and 2 per cent Difco noble agar. A second over-lay containing 1:20,000 neutral red was added 5 days later. Plaque counts were recorded on the 7 th day. In the plaque reduction test for neutralizing antibody, serial 2-fold dilutions of a test serum mixed with equal volumes of virus suspension containing 50 to 75 p.f.u/ $/ 0.1 \mathrm{ml}$ were incubated at $37^{\circ} \mathrm{C}$ for 30 minutes and inoculated in $0.2 \mathrm{ml}$ amounts onto WGM-1 monolayers. At least 10 virus control plates were included in each plaque reduction test. The reciprocal of the highest serum dilution which resulted in a 70 per cent reduction in plaque count was taken as the end-point.

Bemagglutination $(H A)$ and Hemagglutination-Inhibition Tests $(H I)$.- HA and HI tests were carried out according to standard methods (15). Unless otherwise stated, these tests were performed with 0.5 per cent washed guinea pig erythrocyte suspensions.

Complement-Fixation Tests, - These tests were performed according to the method detailed by Hsiung (15). Serum from guinea pigs with antibody titers to SV-5 and WB virus lower than 1:20 was pooled and stored at $-20^{\circ} \mathrm{C}$, and used as the source of complement throughout this study.

Treatment of Sera Prior to Testing for Antibody.-All serum specimens tested for antibody

${ }^{2}$ A stock culture of WI-38 cells at the 14th passage level was kindly supplied by Dr. L. Hayflick of the Wistar Institute, Philadelphia.

${ }^{8}$ Kindly supplied by Dr. H. Koprowski of the Wistar Institute. 
were first treated with trypsin and periodate according to the method outlined by Jensen (16). Before use in an $\mathrm{HI}$ test, the treated serum was adsorbed overnight at $4^{\circ} \mathrm{C}$ with 0.1 volume of packed guinea pig erythrocytes.

Immune Serum for WB Virus.-Hyperimmune serum was produced in rabbits by intravenous inoculation with $1 \mathrm{ml}$ of tissue culture fluid containing $10^{6}$ p.f.u of virus on each of 3 alternate days. One month after the last intravenous inoculation, $1 \mathrm{ml}$ of virus suspension was inoculated subcutaneously. One week later the animals were bled by cardiac puncture.

Chimpanzees were immunized with one dose of virus suspension containing approximately $10^{6}$ p.f.u given subcutaneously and/or intramuscularly. Immune serum was obtained 4 weeks later. ${ }^{4}$

Guinea pigs under light ether anesthesia were infected with virus by dropping $0.1 \mathrm{ml}$ of virus suspension onto the nasal mucous membrane. Three weeks later the animals were bled by cardiac puncture.

Immune Serum for Other Viruses.-Guinea pig antisera for parainfluenza viruses type 1 (sendai and HA-2), type 2 (SV-5 and greer), type 3 (SF and HA-1), type 4 (M-25), and mumps virus, and ferret antisera for measles and respiratory syncytial virus were kindly supplied by Dr. H. Kammer of the Charles Pfizer Company Terre Haute, Indiana, through the Research Reagents Branch of the National Institutes of Health.

Dr. G. R. Sharpless of Lederle Laboratories, Pearl River, New York, provided a generous sample of Newcastle disease virus turkey immune serum. Rabbit antiserum for the SA-1 virus was supplied by Dr. R. N. Hull of the Lilly Research Laboratories, Indianapolis, Indiana. Dr. S. Millian of the New York City Department of Health Laboratories provided the rooster antisera for the influenza $A, A_{1}, B$, and $C$ viruses.

Viruses.-Prototype strains of the myxoviruses were kindly supplied by Dr. R. Chanock and Dr. P. Brunell. SA-1 virus was obtained from Dr. Hull.

Effect of 5-Iododeoxyuridine (5-IUdR) on Virus Multiplication.-WI-38 roller tube cultures were incubated for 3 to 4 hours with $1 \mathrm{ml}$ of maintenance medium containing $10^{-5} \mathrm{M}$ IUdR. The tubes were drained free of medium, inoculated with 100 p.f.u. of virus, and were refed with $1 \mathrm{ml}$ IUdR medium. A set of control cultures receiving regular MEM-2CS was prepared simultaneously. Fluids from all cultures were replaced daily with freshly prepared media. Culture fluids were harvested for plaque assay 48 hours after the appearance of CPE in control cultures. Poliovirus and vaccinia virus controls were included to test the effectiveness of IUdR.

Ether Inactivation.-A suspension of virus in maintenance medium was mixed with an equal volume of peroxide-free diethyl ether at room temperature. The phases were thoroughly mixed and allowed to separate in the cold for 30 minutes. Following removal of the ether, the aqueous phase was assayed for infectivity by the plaque method.

Effect of Acid $p H$ on Viral Infectivity.-A series of $0.1 \mathrm{~m}$ disodium phosphate-citric acid buffer solutions with $\mathrm{pH}$ values ranging from 2.8 to 7.1 were prepared. Virus in tissue culture fluid was mixed with an equal volume of a given buffer solution. Another portion of the same tissue culture fluid was mixed with an equal volume of the $\mathrm{pH} 7.1$ buffer. Both mixtures were kept at $25^{\circ} \mathrm{C}$ for 3 hours, then serially diluted in PBS and titrated for infectivity by the plaque method.

Thermal Inactivation. - A virus suspension in $\mathrm{PBS} \mathrm{pH} 7.2$ containing $10^{-3} \mathrm{M} \mathrm{Ca}^{++}$and $\mathrm{Mg}^{++}$ and 2 per cent calf serum in a thin walled screw capped tube was immersed in a water bath held at a given temperature. At intervals of time thereafter small samples were removed and immediately diluted in cold PBS and titrated for infectivity on WGM-1 monolayers by the plaque method.

Preparation of Tissue Cultures for Microscopic Examination.-Infected and control cultures

\footnotetext{
${ }^{4}$ Animals were kindly made available and immunized by Dr. Robert W. McCollum.
} 
on coverslips were washed three times with PBS and fixed in Bouin's solution for 15 minutes. They were stored in 80 per cent ethanol until stained with hematoxylin and eosin.

\section{RESULTS}

Virus Isolation.-A virus was isolated in cultures of WI-38 cells from each of the following specimens: two urine specimens from MIL collected on the 7th and 6th days before the onset of jaundice in a naturally acquired case of infectious hepatitis; two serum specimens from IRI collected on the 12th and 18th days of the incubation period of experimentally induced infectious hepatitis; and from Willowbrook serum pool 2 (WBSP-2), which was composed of 24 individual serum specimens collected from 18 patients 3 to 7 days before jaundice.

When the 18th day serum from IRI was inoculated into tissue culture, it was also inoculated into a group of 7 human subjects at the Willowbrook State School. ${ }^{5}$ One subject, MAC, developed anicteric hepatitis 56 days later. Serial serum specimens collected from MAC at intervals during the incubation period, and acute and convalescent phases of the disease were tested in tissue culture. As shown in Table I a virus was isolated from a number of the serum specimens collected during the early and late incubation period. No virus was isolated from the preinoculation serum or from the serum collected on the 12th, 19th, 26th, and 56th days following the inoculation of the test serum.

Each of the three patients did develop a 4 -fold or greater rise in titer of specific neutralizing antibody (Table I).

It is of interest to note here that WBSP-2 has produced hepatitis in 12 of 22 human volunteers (9), and in a recent study (17) the 12th day serum from IRI induced anicteric hepatitis in one member of a group of 6 subjects.

WI-38 roller tube cultures inoculated with the urine samples from patient MIL developed little if any CPE by the 7th day. After one blind passage however, CPE became apparent. Similarly, the serum samples from IRI, MAC, and WBSP-2 required one or more blind passages in WI-38 cultures before CPE became evident. All isolations were confirmed by reisolation from the original specimens in WI-38 cells prepared from a stock culture which was received in this laboratory several months after all the primary isolations had been made.

Two sets of control cultures, one uninoculated, and the other inoculated with serum from patients having no clinical or chemical evidence of hepatitis, failed to yield a cytopathic agent after 6 or more blind passages. The data relating to the isolations are summarized in Table I.

Serologic Interrelationship of the Viruses Isolated.-Levels of neutralizing and $\mathrm{HI}$ antibody in immune rabbit sera were determined for each isolate after three

\footnotetext{
${ }^{5}$ The justification for these human volunteer studies was described in detail in a previous publication (7).
} 
end-point dilution passages in WI-38 cells. The individual agents could not be differentiated from one another serologically (Table II). Accordingly they were considered to represent a single virus referred to hereafter as WB (Willowbrook) virus.

Serial Passage and Host Range.-Each WB virus isolate was serially passaged in cultures of WI-38, WGM-1, HEK, and HeLa cells. The virus was capable

TABLE I

Virus Isolations and Serologic Evidence of Infection

\begin{tabular}{|c|c|c|c|c|c|}
\hline \multirow{2}{*}{ Patient } & \multirow{2}{*}{ Specimen } & \multirow{2}{*}{ Day } & \multirow{2}{*}{$\begin{array}{c}\text { Designation } \\
\text { of isolate }\end{array}$} & \multicolumn{2}{|c|}{ Neutralizing antibody titer* } \\
\hline & & & & Preinoculation & Convalescent \\
\hline MIL $\ddagger$ & $\begin{array}{l}\text { Urine } \\
\text { Urine }\end{array}$ & $\begin{array}{l}\mathrm{J}-78 \\
\mathrm{~J}-6\end{array}$ & WB39 & 8 & 32 \\
\hline IRI & $\begin{array}{l}\text { Serum } \\
\text { Serum }\end{array}$ & $\begin{array}{l}12 \| \\
18\end{array}$ & WB12 & 32 & 128 \\
\hline MAC 9 & $\begin{array}{l}\text { Serum } \\
\text { Serum } \\
\text { Serum } \\
\text { Serum } \\
\text { Serum }\end{array}$ & $\begin{array}{c}5 \| \\
33 \\
36 \\
40 \\
50\end{array}$ & WB43 & $<8$ & 64 \\
\hline WBSP-2 & Pooled serum & $\mathrm{J}-3$ to $-7^{* *}$ & WBSP-2 & NTł & NT $¥ t$ \\
\hline
\end{tabular}

* Determined by plaque reduction.

$\ddagger$ Naturally acquired infectious hepatitis.

$\$$ Urine collected on the 7 th and 6 th days before the outset of jaundice.

|| Day following inoculation of infectious serum.

I Serum collected before inoculation and on the 12th, 19th, 26th, and 56th days after inoculation were all negative after 6 blind tissue culture passages.

** Pooled serum collected from 18 individual patients 3 to 7 days before the outset of jaundice.

$\ddagger \ddagger$ Individuals contributing to the serum pool were not tested.

of optimal growth on first passage in WGM-1 and HEK cultures. Peak titers of $10^{8} \mathrm{p} . \mathrm{f} . \mathrm{u} / \mathrm{ml}$ were attained within 48 to 60 hours after infection. In WI-38 cultures peak titers of $10^{6} \mathrm{p} . \mathrm{f} . \mathrm{u} / \mathrm{ml}$ were attained by 48 hours. On first passage in HeLa cells, the virus grew to titers of $10^{4}$ p.f.u $/ \mathrm{ml}$ in 7 or 8 days, and appeared to require several serial passages in these cultures before optimal growth was achieved.

The viruses serially propagated in each of these cell systems were reidentified by neutralization with WB antiserum.

The virus was not pathogenic for suckling mice by intracerebral, intravenous, 
or intraperitoneal routes of inoculation. No growth of WB virus in embryonated eggs was detected after two serial passages of virus-infected tissue culture fluid.

Cytopathic Effects (CPE).-In infected WI-38 cultures CPE began with the development of focal areas of granularity. The granules became progressively coarse, dense, and irregular, and finally appeared to be the remnants of disintegrated cells. Within 48 hours the entire cell sheet appeared laden with granular debris (Figs. $1 a$ and $1 b$ ). A few small multinucleated cells were observed in cultures which were fixed and stained (Fig. 2).

The initial change observed in infected WGM-1 cultures was the presence of syncytial areas which rapidly enlarged to involve most of the cell sheet.

TABLE II

Serologic Interrelationship of the Viruses Isolated

\begin{tabular}{|c|c|c|c|c|}
\hline \multirow{3}{*}{ Test virus } & \multicolumn{4}{|c|}{$\begin{array}{l}\text { Reciprocal of antibody titer in rabbit antiserum prepared against the } \\
\text { indicated virus }\end{array}$} \\
\hline & \multicolumn{2}{|c|}{ WB12 } & \multicolumn{2}{|c|}{ WB39 } \\
\hline & $\mathrm{HI}^{*}$ & Neut & $\mathrm{HI}$ & Neut \\
\hline WB12 & 256 & 64 & 512 & 128 \\
\hline WB39 & 256 & 64 & 256 & 128 \\
\hline WB43 & 128 & 64 & 512 & 128 \\
\hline WBSP-2 & 256 & 64 & 512 & 128 \\
\hline
\end{tabular}

* Here and in the following tables: HI, hemagglutination-inhibition tests; and neut, neutralization tests.

Areas of syncytium became coarsely granular and refractile, and ultimately shrank away from the surrounding cell sheet as dense, irregularly shaped masses with no discernible structure (Figs. $3 a$ and $3 b$ ).

The characteristic eosinophilic intracytoplasmic inclusions described in tissue cultures infected with other members of the parainfluenza group $(18,19)$ were not observed in fixed and stained WB virus-infected WGM-1 cultures (Fig. 4).

The cytopathology seen in HeLa cells was limited to the formation of multinucleated giant cells which were not nearly as large as the syncytia which developed in WGM-1 cultures. The giant HeLa cells rarely contained more than 10 to 15 nuclei. No inclusion bodies were observed.

Plaque Formation.-WB virus produced plaques on monolayers of WGM-1 and WI-38 cells. On WGM-1 monolayers plaques appeared by the 5th day and became maximal in number by the 7 th day. They were round with slightly ragged borders and measured 1 to $2 \mathrm{~mm}$ in diameter (Fig. 5). 
The number of plaques per dish increased linearly with increasing concentrations of WB virus as documented in Text-fig.1. The deviation from linearity at plaque densities greater than 100 per dish was probably due to confluence of plaques.

Formation of plaques was prevented when a virus suspension was incubated with a 1:100 dilution of WB antiserum prior to assay.

Hemagglutination and Hemadsorption.-Fluids from infected WI-38, WGM1 , and HeLa cell cultures agglutinated guinea pig, human type $\mathrm{O}$, and chicken

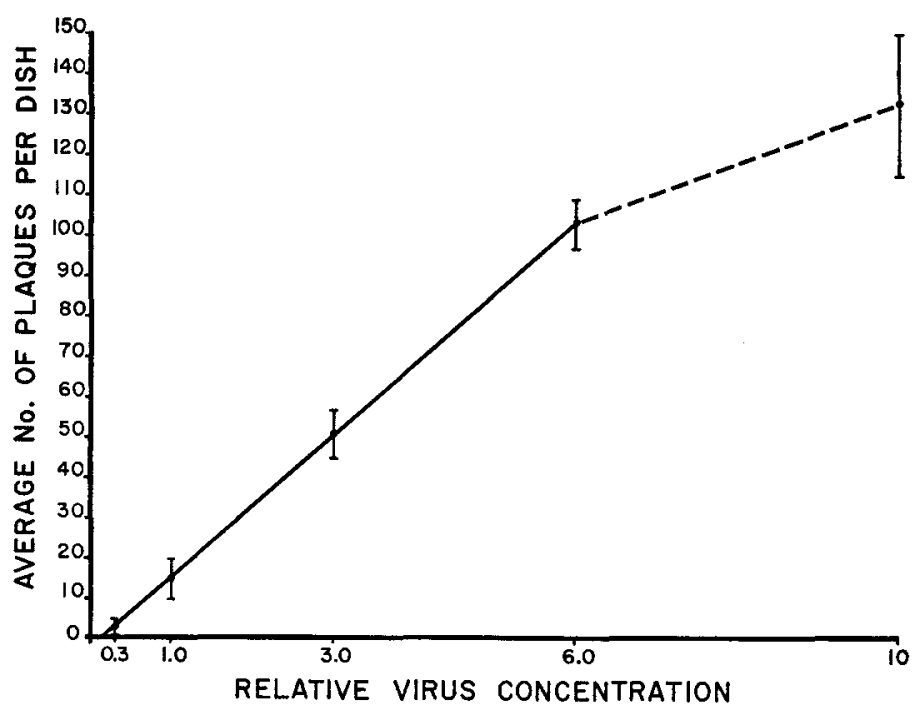

TExx-FIG. 1. Relationship between plaque count and relative virus concentration. Solid line represents the range of virus concentration over which plaque count varies linearly. The broken line indicates the deviation from linearity at plaque densities greater than 100 per dish.

erythrocytes. Optimal titers were obtained when guinea pig erythrocytes were agglutinated at 4 or $25^{\circ} \mathrm{C}$, or when 1-day-old chick erythrocytes were agglutinated at $4^{\circ} \mathrm{C}$ (Table III).

Receptors for WB virus hemagglutinin were removed from guinea pig erythrocytes by neuraminidase. Incubation of guinea pig erythrocytes with WB virus for 24 hours at $37^{\circ} \mathrm{C}$ also resulted in the removal of receptors.

Infected WGM-1, HEK, and HeLa cell cultures strongly and confluently adsorbed guinea pig erythrocytes. Infected WI-38 cultures however did not adsorb guinea pig erythrocytes to nearly the same degree, perhaps because the early cytopathic changes in WI-38 cultures resulted in cellular disintegration.

Effect of $5^{\prime} I U d R$ on the Replication of WB Virus.-WB virus replication in WI-38 cultures was not inhibited in the presence of $10^{-5} \mathrm{M}$ IUdR. This concen- 
tration of IUdR was sufficient to cause a 1000 -fold reduction in the yield of vaccinia virus. The results of these experiments are summarized in Table IV. IUdR at $10^{-4} \mathrm{M}$ did not inhibit the replication of vaccinia virus in WGM-1 cells and on this basis appears not to be an effective inhibitor of DNA synthesis in these cells.

Ether Sensitivity.-WB virus infectivity was destroyed by 50 per cent ethyl ether at $4^{\circ} \mathrm{C}$ for 30 minutes.

TABLE III

Effect of Erythrocyte and Temperature on the Titer of WB Virus Hemagglutinin

\begin{tabular}{c|c|c|c}
\hline \multirow{2}{*}{ Temperature } & \multicolumn{2}{|c|}{ Reciprocal of bemagglutinin titer with indicated erythrocytes } \\
\cline { 2 - 3 } & Guinea pig & Chick & Human O \\
\hline${ }^{\circ} \mathrm{C}$ & 32 & 32 & \\
4 & 32 & $<2$ & 16 \\
25 & $<2$ & $<2$ & 16 \\
37 & & $<2$ \\
\hline
\end{tabular}

TABLE IV

Effect of 5' Iododeoxyuridine (5'IUdR) on Replication of WB Virus in WI-38 Cells

\begin{tabular}{l|c|c|c}
\hline \multirow{2}{*}{ Virus } & \multicolumn{2}{|c|}{ Infectivity titer (p.f.u./ml) } & $\begin{array}{c}\text { Log 10 difference in titer } \\
\text { (Control - IUdR) }\end{array}$ \\
\cline { 2 - 3 } & Control & $10^{-5} \mathrm{M}$ IUdR & \\
\hline WB39 & $20 \times 10^{4}$ & $25 \times 10^{4}$ & -0.10 \\
WB12 & $20 \times 10^{5}$ & $29 \times 10^{5}$ & -0.16 \\
WBSP-2 & $16 \times 10^{4}$ & $38 \times 10^{4}$ & -0.37 \\
Poliovirus type 1 & $80 \times 10^{5}$ & $90 \times 10^{5}$ & -0.05 \\
Vaccinia & $13 \times 10^{5}$ & $14 \times 10^{2}$ & +3.0 \\
\hline
\end{tabular}

Thermal Inactivation.-The kinetics of inactivation of WB virus at various temperatures are presented in Text-fig. 2. Virus was suspended in PBS $\mathrm{pH} 7.2$ containing $10^{-3} \mathrm{M} \mathrm{Ca}^{++}$and $\mathrm{Mg}^{++}$and 2 per cent calf serum. The virus is stable at $-65^{\circ} \mathrm{C}$ for at least 12 months. The inactivation constant and the half-life of virus infectivity at various temperatures are listed in Table V.

Effect of $p H$ on Infectivity. - According to the criterion of Tyrrell and Chanock (20), WB virus appeared to be "acid resistant", since less than a 100-fold reduction in infectivity resulted when virus was held at $\mathrm{pH} 2.8$ for 3 hours. In Table VI, are summarized the results of experiments which tested the effect of various $\mathrm{pH}$ 's on WB virus infectivity.

Size Determination.-Negatively stained preparations of WB virus were examined in the electron microscope by Prose et al. (21). Intact virus particles 
were observed which varied in size from 100 to approximately $300 \mathrm{mu}$ in greatest diameter.

Serologic Relationship between WB Virus and Members of the Myxovirus Group.-There was no evidence of antigenic relatedness of WB virus to influ-

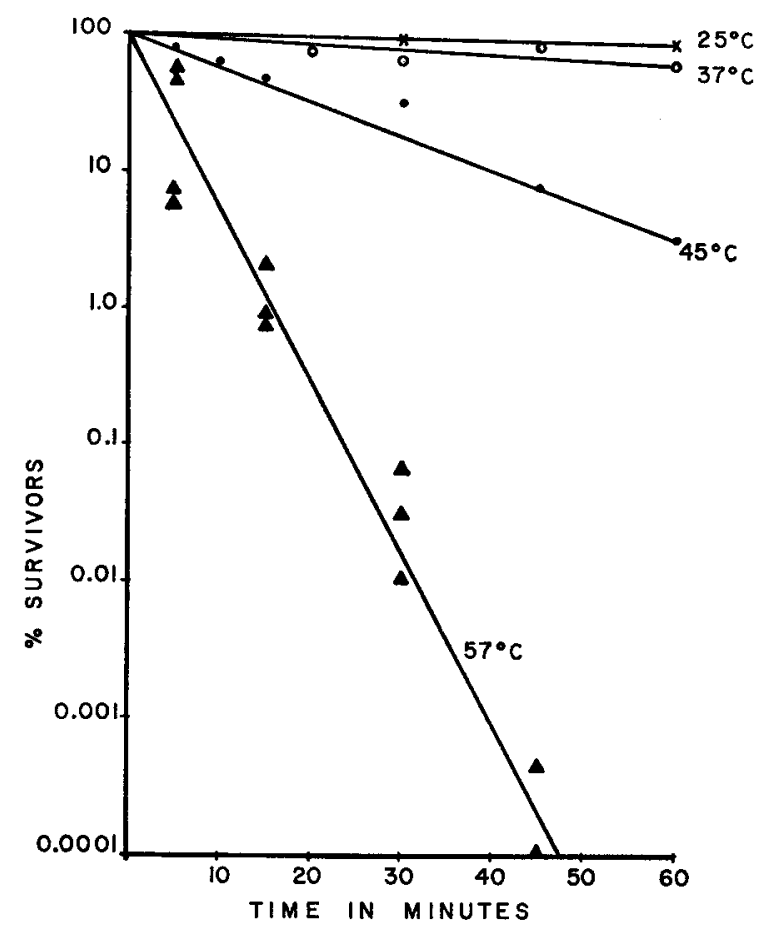

TEXT-FIg. 2. Rate of thermal inactivation of WB virus at various temperatures. Virus was suspended in PBS pH 7.2, containing $10^{-3} \mathrm{M} \mathrm{Ca}^{++}$and $\mathrm{Mg}^{++}$and 2 per cent calf serum.

TABLE V

Thermal Inactivation Constant and Half-Life of WB Virus at Various Temperatures

\begin{tabular}{c|c|c}
\hline Temperature & $\mathbf{k}\left(\min { }^{-1}\right)^{*}$ & $\mathbf{t}_{1 / 2} \ddagger$ \\
\hline${ }^{\circ} \mathrm{C}$ & & \\
57 & 0.295 & 2.5 minutes \\
45 & 0.049 & 14 minutes \\
37 & 0.004 & 3.2 hours \\
22 & 0.002 & 7.7 hours \\
4 & 0.001 & 22.6 hours \\
\hline
\end{tabular}

* Inactivation constant.

$\ddagger$ Half-life. 
enza virus types $A_{1}, A_{2}, B$, and $C$, measles virus or respiratory syncytial virus by reciprocal $\mathrm{HI}$ or neutralization tests. The results of neutralization and $\mathrm{HI}$ tests employing hyperimmune sera prepared against various members of the mumps-NDV-parainfluenza group are summarized in Table VII. These results

TABLE VI Effect of Acid $p H$ on Infectivity of $W B$ Virus

\begin{tabular}{c|c|c}
\hline Experiment & $\mathrm{pH}^{*}$ & Titer (p.f.u./ml) \\
\hline 1 & 3.6 & $3.5 \times 10^{4}$ \\
4.7 & $8.0 \times 10^{4}$ \\
5.7 & $5.2 \times 10^{4}$ \\
7.1 & $2.0 \times 10^{4}$ \\
& 2.8 & $1.5 \times 10^{8}$ \\
& 7.1 & $8.2 \times 10^{8}$ \\
\hline
\end{tabular}

* Final pH reading after equal volumes of virus suspension were mixed with equal volumes of each buffer and held at $25^{\circ} \mathrm{C}$ for 3 hours.

TABLE VII

Relationship of WB Virus to Viruses of the Mumps-NDV-Parainfluenza Group by Neutralization and HI Tests Employing Hyperimmune Prototype Sera

\begin{tabular}{|c|c|c|c|c|c|c|c|c|c|c|c|c|c|c|}
\hline \multirow{4}{*}{ Virus } & \multicolumn{14}{|c|}{ Neutralization and $\mathrm{HI}$ antibody titer in prototype serum } \\
\hline & \multicolumn{8}{|c|}{ Parainfluenza* } & \multirow{2}{*}{\multicolumn{2}{|c|}{ SV-5* }} & \multirow{2}{*}{\multicolumn{2}{|c|}{ Mumps* }} & \multirow{2}{*}{\multicolumn{2}{|c|}{ NDV }} \\
\hline & \multicolumn{2}{|c|}{$\stackrel{1}{1}{ }_{\text {Sendai }}$} & \multicolumn{2}{|c|}{$\stackrel{2}{\text { Greer }}$} & \multicolumn{2}{|c|}{ HA-1 } & \multicolumn{2}{|c|}{$\stackrel{4}{4-25}$} & & & & & & \\
\hline & HI & Neut & $\mathrm{HI}$ & Neut & $\mathrm{HI}$ & Neut & HI & Neut & HI & Neut & $\mathrm{HI}$ & Neut & HI & Neut \\
\hline Homologous & 512 & 128 & 512 & 64 & 512 & 64 & NT\& & NT & 2048 & $\geq 256$ & 2048 & 512 & NT & 256 \\
\hline WB39 & $<8$ & $<16$ & 32 & $<16$ & $<8$ & $<16$ & $<8$ & $<16$ & 2048 & $\geq 256$ & 16 & $<16$ & NT & $<16$ \\
\hline
\end{tabular}

* Hyperimmune guinea pig sera.

$\ddagger$ Hyperimmune turkey serum.

$\S$ Not tested.

indicated a close relationship of WB virus to the SV-5 and greer type -2 parainfluenza viruses. Since the sera employed were from hyperimmunized guinea pigs, the results should be interpreted with caution. The need for careful interpretation is further justified by the data in Table VIII, which indicate the level and prevalence of WB antibody in populations of "normal" guinea pigs. From the group of 100 guinea pigs that provided the hyperimmune SV-5 serum used in these tests, samples of preimmunization sera were available from 10 (group 
I, Table VIII). These sera, together with sera from 11 "normal" guinea pigs obtained from a breeder in another part of this country (group II, Table VIII), were tested for levels of WB and SV-5 antibody. Each of the 10 animals immunized with SV-5 virus had significant preimmunization levels of WB antibody. Furthermore, of the 21 animals tested, 20 had WB HI antibody titers of $1: 32$ or higher.

TABLE VIII

Prevalence of $H I$ Antibody to WB and SV-5 Viruses in Two Groups of "Normal" Guinea Pigs

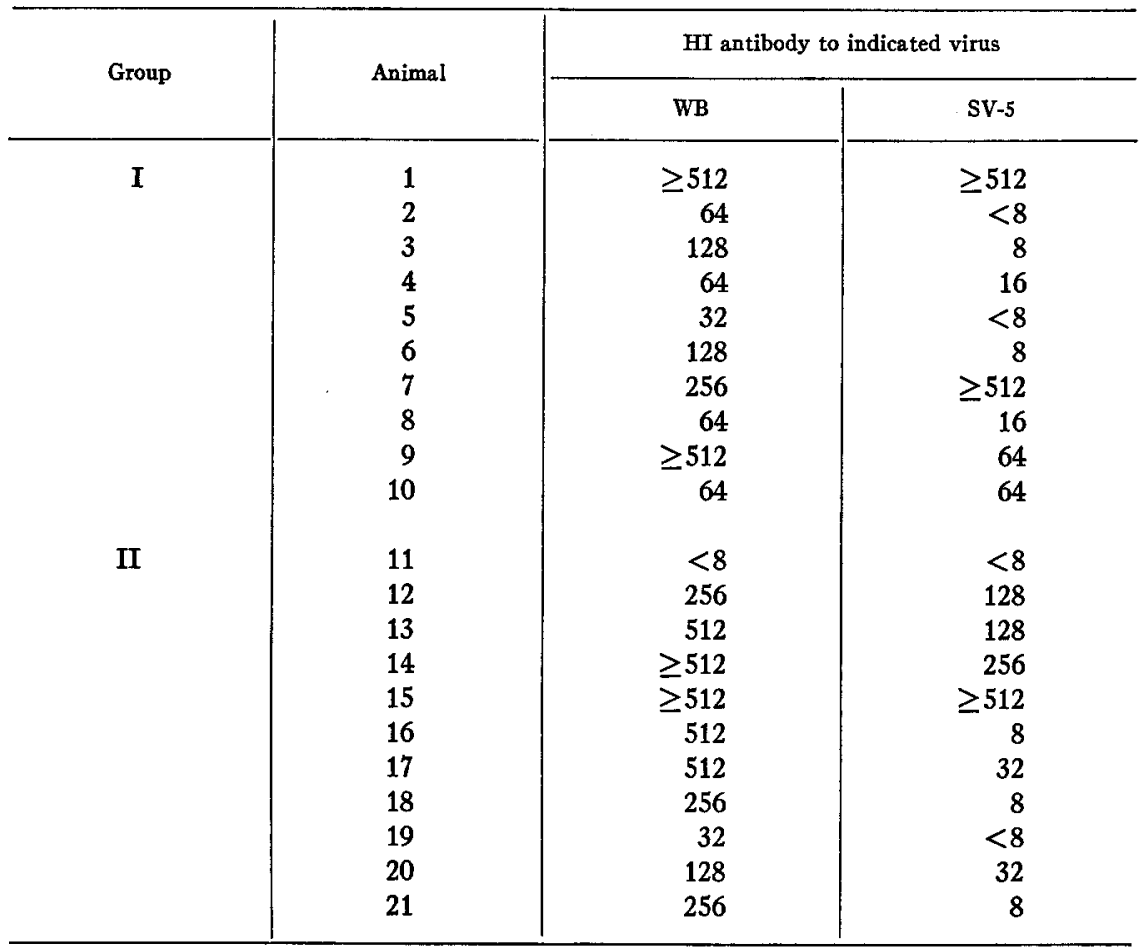

Definitive serologic data were obtained by comparing serum antibody levels in animals before and after immunization with WB or SV-5 virus. The results which are presented in Table IX demonstrated that WB virus was clearly differentiated from the simian and human type-2 viruses. Some degree of antigenic similarity to SV-5 is suggested by the reciprocal rise in SV-5 antibody in 3 of the 4 WB-immunized animals. The SV-5 infected guinea pig however did not develop a reciprocal rise in WB antibody. There was in these experiments no evidence of a relationship to the human (greer) type-2 virus.

Relationship of WB Virus to Viruses other than Myxoviruses.-WB virus was 
antigenically distinct from herpes simplex and the simian virus SA-1 (22), which produces CPE in WGM-1 and HeLa cultures that is indistinguishable from the CPE produced by WB virus.

TABLE IX

Relationship Between WB, SV-5, and Parainfluenza Type-2 Viruses

\begin{tabular}{|c|c|c|c|c|c|c|c|}
\hline \multirow{3}{*}{ Animal and immunization } & \multirow{3}{*}{ Test viruses } & \multicolumn{6}{|c|}{ Antibody titer to indicated virus } \\
\hline & & \multicolumn{3}{|c|}{ Preimmunization } & \multicolumn{3}{|c|}{ Postimmunization } \\
\hline & & HI & Neut & C-F & $\mathrm{HII}$ & Neut & C-F \\
\hline \multirow{4}{*}{$\begin{array}{c}\text { Chimpanzee 5-6 immu- } \\
\text { nized with WB virus }\end{array}$} & Parainfluenza-2 & 8 & & & 8 & & \\
\hline & Parainfluenza-3 & $<8$ & & & $<8$ & & \\
\hline & SV-5 & $<8$ & & $<8$ & 64 & & $<8$ \\
\hline & WB virus & $<8$ & & & 512 & & 8 \\
\hline \multirow{4}{*}{$\begin{array}{c}\text { Chimpanzee 5-7 immu- } \\
\text { nized with WB virus }\end{array}$} & Parainfluenza-2 & 16 & & & 16 & & \\
\hline & Parainfluenza-3 & $<8$ & & & $<8$ & & \\
\hline & SV-5 & $<8$ & & $<8$ & 16 & & $<8$ \\
\hline & WB virus & $<8$ & & $<8$ & 128 & & $<8$ \\
\hline \multirow{3}{*}{$\begin{array}{l}\text { Rabbit } 1-2 \text { immunized } \\
\text { with WB virus }\end{array}$} & Parainfluenza-2 & $<8$ & & & $<8$ & & \\
\hline & SV-5 & $<8$ & & $<8$ & $<8$ & & $<8$ \\
\hline & WB virus & $<8$ & & $<8$ & 128 & & 8 \\
\hline \multirow{3}{*}{$\begin{array}{l}\text { Rabbit 3-9 immunized } \\
\text { with WB virus }\end{array}$} & Parainfluenza-2 & 8 & 8 & & 8 & 8 & \\
\hline & SV-5 & 8 & $<8$ & $<8$ & 64 & 8 & $<8$ \\
\hline & WB virus & $<8$ & $<8$ & $<8$ & 512 & 128 & 8 \\
\hline \multirow{2}{*}{$\begin{array}{l}\text { Guinea pig } 8-9 \text { infected } \\
\text { with SV-5 }\end{array}$} & SV-5 & $<8$ & $<8$ & & 128 & 256 & \\
\hline & WB virus & 32 & 16 & & 32 & 32 & \\
\hline
\end{tabular}

DISCUSSION

WB virus possesses the chemical and physical properties which are characteristic of the parainfluenza viruses. These include a particle size range of $\mathbf{1 0 0}$ to $300 \mathrm{~m} \mu$, sensitivity to ether, a nucleic acid component which is most probably RNA, the capacity to agglutinate fowl and mammalian erythrocytes, and the loss of this capacity following destruction of erythrocyte receptors by neuraminidase or virus hemagglutinin. In addition, WB virus-infected tissue culture has the capacity to adsorb erythrocytes (hemadsorption). The infectivity of the virus is best preserved at temperatures below $-60^{\circ} \mathrm{C}$.

The morphology of WB virus demonstrated in the electron microscopic studies of Prose et al. (21) provides further justification for classifying WB virus in the mumps-NDV-parainfluenza group. 
WB virus can be differentiated serologically from the known parainfluenza viruses. A relationship to SV-5 is suggested by the reciprocal rise of SV-5 antibody titers in WB-immunized animals. Homologous antibody titers are at least 8-fold higher than heterologous titers. Though no reciprocal rise in WB antibody developed in SV-5-infected guinea pigs, it is reasonable at present to regard WB virus as a serologically distinct virus which bears some antigenic relationship to the type-2 simian parainfluenza viruses.

The apparent relationship to SV-5 raises the possibility that WB virus may have been isolated as a contaminant from tissue cultures infected with a simian virus. That the agents recovered in this study most probably represent isolations from the patient material rather than contamination of WI-38 cultures by simian agents is supported by the following observations. (a) Specimens for primary isolation were inoculated into WI-38 tissue cultures only. The pipette which was used to introduce the specimen into the WI-38 culture did not come in contact with any other type of tissue culture at the time of inoculation. (b) Reisolation from each of the original positive specimens was accomplished in a new stock of WI-38 cells received in this laboratory 3 months after the primary isolations had been made. $(c)$ Negative specimens on repeated reisolation attempts remained negative during 6 blind tissue culture passages. (d) Duplicate serum specimens collected from patient MAC before the inoculation of infectious material and on the 33rd day of the incubation period never entered this laboratory. They were sent under coded designations to the laboratory of Dr. R. W. McCollum in New Haven where they were tested in WI-38 and continuous African green monkey kidney cultures. Virus was isolated from the 33rd day specimen and not from the preinoculation specimen. (e) Each of the patients from whom virus was isolated developed a greater than 4 -fold rise in serum neutralizing antibody.

Hsiung et al. (23) presented evidence that the DA virus, which is antigenically indistinguishable from SV-5, infected humans. Though the recovery of the DA virus was made under conditions which apparently precluded contamination of the clinical specimen with SV-5, the conclusion regarding human infection by DA virus was not generally accepted (19).

The present findings tend to support the view of Hsiung et al. (23) that humans may be infected with viruses antigenically identical or related to a virus which naturally infects monkeys. The work of Hsiung and coworkers is of interest in another regard, since the DA virus was isolated from the blood of a patient who died with infectious hepatitis.

Whether WB virus is from the ecologic standpoint primarily a human virus or a simian virus is an interesting question, but one which lies beyond the scope of the present work.

Present knowledge of the properties of the virus of infectious hepatitis has been derived from human volunteer experiments. The number of properties 
thus recognized is understandably small. It is known that the virus survived temperatures of $56^{\circ} \mathrm{C}$ for 30 minutes, or -10 to $-20^{\circ} \mathrm{C}$ for 18 months. The virus was not inactivated in the presence of 10 per cent ether at $4^{\circ} \mathrm{C}$ for 24 hours. The infectious particle passed through a seitz EK filter (24). The diffculties involved in the design and conduct of human volunteer experiments are manifold. Furthermore, interpretation of the results of such studies, especially with the virus of infectious hepatitis, may be difficult since there is no simple objective way of assessing variations in host resistance or susceptibility to infection. Well matched control groups must be included in each study which nonetheless may yield results subject to conflicting interpretation.

The demonstration of a relationship between WB virus and infectious hepatitis by serologic means presents additional difficulties. The significance of a rise in a specific type parainfluenza antibody in humans over 6 to 10 years of age is difficult to interpret, since heterotypic antibody responses are known to occur with increasing frequency with age (19). This difficulty is particularly troublesome in an institutional setting where both parainfluenza virus infections and infectious hepatitis are common. The detection of WB antibody in Willowbrook patients with infectious hepatitis is of little significance in documenting the existence of a causal relationship between WB virus infection and this disease.

It is our impression that WB virus is probably not the causative agent of infectious hepatitis. Although, from the available data it is impossible to state that the virus is not related to the disease. The nature of the problem is such that it can be resolved only by attempting to fulfill Koch's postulates. However, the administration of WB virus to human subjects cannot be justified before a more positive relationship is established between the virus and infectious hepatitis.

\section{SUMMARY}

A virus has been isolated from the serum and urine of patients with infectious hepatitis. This virus is a member of the parinfluenza group. It is serologically distinct from the known members of the group, but apparently is antigenically related to the simian type-2 parainfluenza viruses.

A causal relationship between WB virus and infectious hepatitis has not been established.

The authors are indebted to Miss Norie Yasukawa for her competent technical assistance, and to Mrs. Harriet Friedman and Mrs. Cass Lattimer for their cooperation with various phases of the serologic testing.

We wish also to acknowledge the valuable suggestions and material aid received from Dr. R. W. McCollum and Dr. R. N. Chanock, and the cooperation of Dr. Jack Hammond, Director, Willowbrook State School.

\section{BIBLIOGRAPHY}

1. Henle, W., Harris, S., Henle, G., Harris, T. N., Drake, M. E., Mangold, F., and Stokes, J., Jr., Studies on the agent of infectious hepatitis 1. Propagation of the 
agent in tissue culture and in the embryonated hen's egg, J. Exp. Med., 1950, 92, 271.

2. Rightsel, W. A., Keltsch, R. A., Tekushan, F. M., and McLean, I. W., Jr., Cultivation of cytopathogenic agents from patients with clinical hepatitis, Science 1956, 124, 226.

3. Davis, E. V., Isolation of viruses from children with infectious hepatitis, Science, 1961, 133, 2059.

4. Bolin, V. S., Alsever, J. B., Barger, J. B., and Jarvis, T. B., Studies on serum and infectious hepatitis of man 1. Preliminary report on the isolation of serum and infectious hepatitis viruses from man in tissue culture, Transfusion, 1961, 1, 360.

5. O'Malley, J. P., Meyer, H. M., and Smadel, J. E., Antibody in hepatitis patients against a newly isolated virus, Proc. Soc. Exp. Biol. and Med., 1961, 108, 200.

6. Taylor, A. R., Rightsel, W. A., Boggs, J. D., and McLean, I. W., Jr., Tissue culture of hepatitis virus, Am. J. Med., 1962, 32, 679.

7. Ward, R., Krugman, S., Giles, J. P., Jacobs, A. M., and Bodansky, O., Infectious hepatitis: Studies of its natural history and prevention, New England J. Med., 1958, 258, 407.

8. Krugman, S., Ward, R., Giles, J. P., Bodansky, O., and Jacobs, A. M., Infectious hepatitis: Detection of virus during the incubation period and in clinically inapparent infection, New England J. Med., 1959, 261, 729.

9. Krugman, S., Ward, R., and Giles, J. P., The natural history of infectious hepatitis, Am. J. Med., 1962, 32, 717.

10. Liebhaber, H., Krugman, S., Giles, J. P., and McGregor, D. M., Recovery of cytopathic agents from patients with infectious hepatitis: Isolation and propagation in cultures of human diploid lung fibroblasts (WI-38), Virology, 1964, 24, 109.

11. Eagle, H., Amino acid metabolism in mammalian cell cultures, Science, 1959, 130, 432.

12. Chanock, R. M., Johnson, K. M., Cook, M. K., Wong, D. C., and Vargasco, A., The hemadsorption technique with special reference to the problem of naturally occurring simian parainfluenza viruses, Am. Rev. Respirat. Diseases 1961, 83, 125.

13. Reed, L. J., and Muench, H., A simple method of estimating fifty per cent endpoints, Am. J. Hyg., 1938, 27, 493.

14. Dulbecco, R., and Vogt, M., Plaque formation and isolation of pure lines with poliomyelitis viruses, J. Exp. Med., 1954, 99, 167.

15. Hsiung, G. D., Diagnostic Virology, New Haven, Yale University Press, 1964.

16. Jensen, K., Diagnosis of influenza by serologic methods, Am. Rev. Respirat. Diseases, 1961, 83, 120.

17. Giles, J. P., Liebhaber, H., Krugman, S., and Lattimer, C., Early viremia and viruria in infectious hepatitis, Virology, 1964, 24, 107.

18. Lepine, P., Chany, C., Droz, B., and Robbe-Fossat, F., Cytopathogenic effect of two newly recognized myxovirus strains: Mechanism of syncytial formation, Ann. New York Acad. Sc., 1959, 81, 62.

19. Chanock, R. M., Parrott, R. H., Johnson, K. M., Kapikian, A. Z., and Bell, J. A., Myxoviruses: Parainfluenza, Am. Rev. Respirat. Diseases, 1963, 88, 152. 
20. Tyrrell, D. A. J., and Chanock, R. M., Rhinoviruses: A description, Science, 1963, 141, 152.

21. Prose, P. H., Liebhaber, H., Balk, S., and Krugman, S., Studies of a myxovirus recovered from patients with infectious hepatitis II. Fine structure and electronmicroscopic demonstration of intracytoplasmic internal component and viral filament formation, $J$. Exp. Med., 1965, 122, 1151.

22. Malherbe, H., and Harwin, R., Seven viruses isolated from the vervet monkey, Brit. J. Exp. Path., 1957, 38, 539.

23. Hsiung, G. D., Isaacson, P., and McCollum, R. W., Studies of a myxovirus isolated from human blood 1. Isolation and properties, J. Immunol., 1962, 88, 284.

24. Havens, W. P., Jr., and Paul, J. R., Infectious hepatitis and serum hepatitis, in Viral and Rickettsial Infections of Man, (Rivers, T., and Horsfall, F. L., Jr., editors) Philadelphia, J. P. Lippincott, 1959, 570.

\section{EXPLANATION OF PLATES}

\section{Plate 66}

FIGs. $1 a$ and $1 b$. Fig. $1 a$, uninfected WI-38 culture. Fig. $1 b$, WI-38 culture 96 hours after infection with WB virus. Both preparations are unfixed and unstained. $\times 290$.

FIG. 2. Multinucleated cell from WI-38 culture infected with WB virus. Hematoxylin and eosin stained. $\times 390$. 


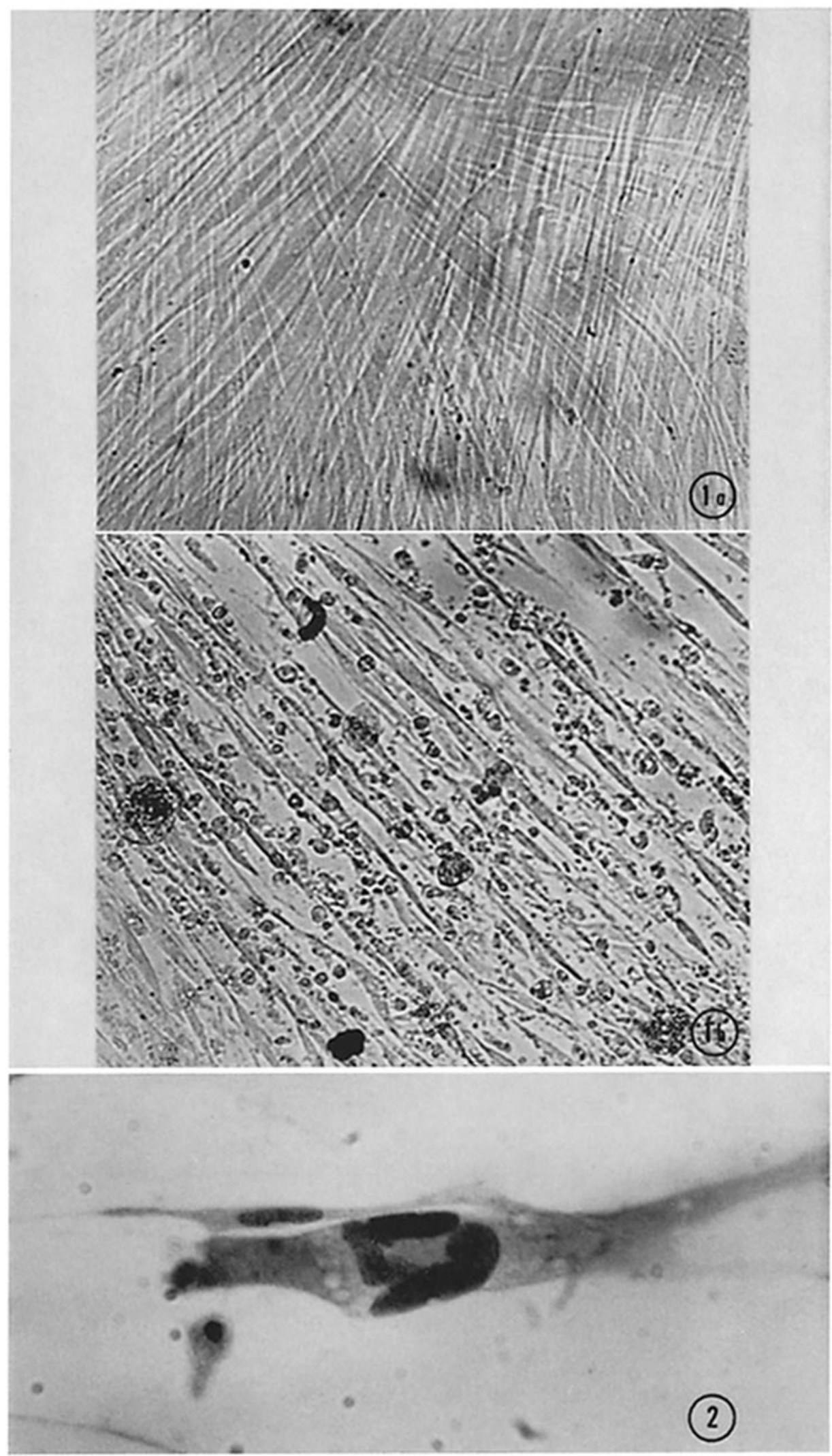

(Liebhaber et al.: Myxovirus and infectious hepatitis. I) 


\section{Plate 67}

Figs. $3 a$ and $3 b$. Fig. $3 a$, uninfected WGM-1 culture. Fig. $3 b$, WGM-1 culture 72 hours after infection with WB virus. Both preparations are unfixed and unstained. $\times 300$. 


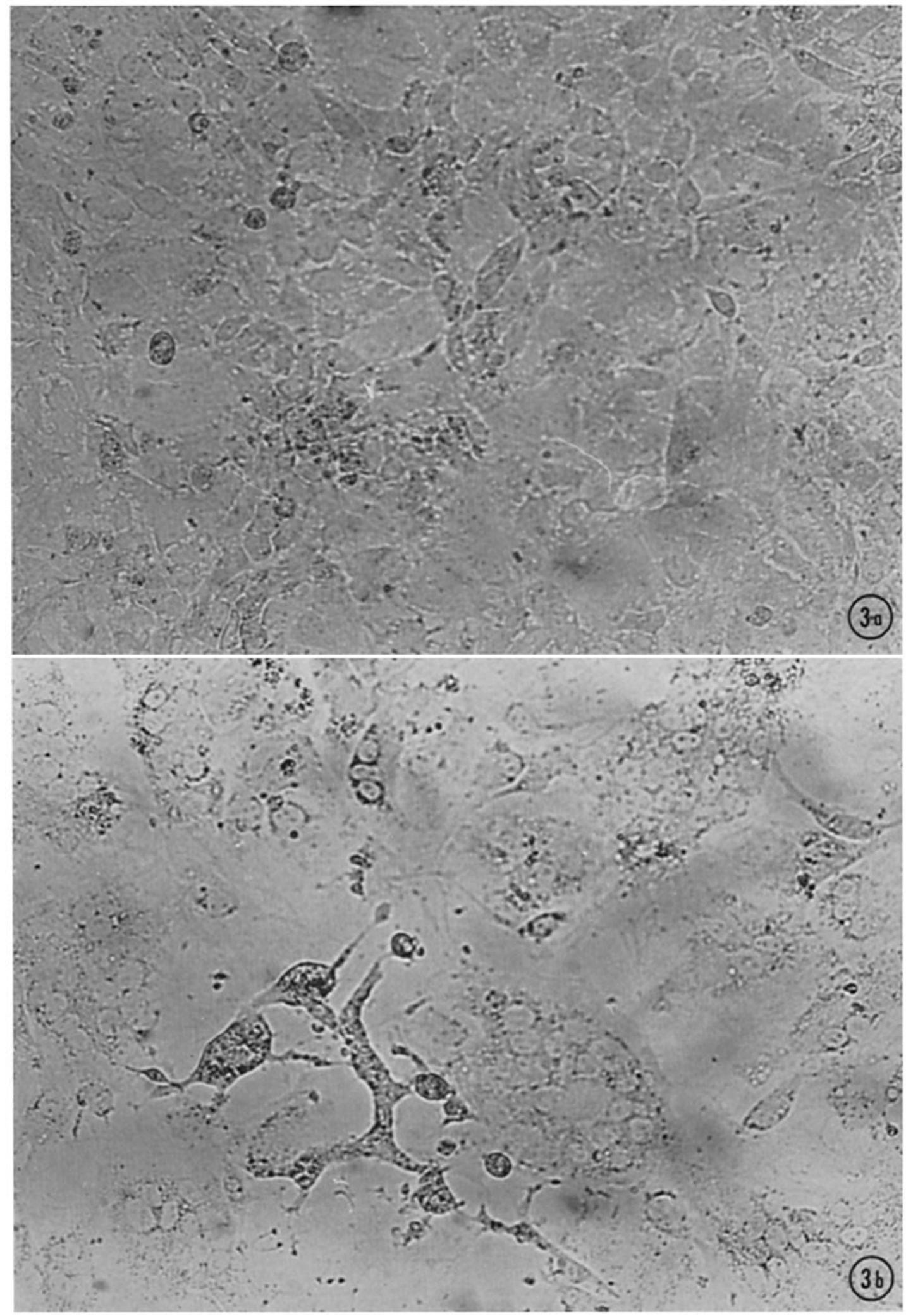

(Liebhaber et al.: Myxovirus and infectious hepatitis. I) 
Plate 68

FIG. 4. WB virus-infected WGM-1 culture. Fixed in Bouin's solution and stained with hematoxylin and eosin. $\times 175$.

FIG. 5. WB virus plaques on WGM-1 monolayers. Uninoculated monolayer is included for comparison. $\times 1.1$. 
THE JOURNAL OF EXPERIMENTAL MEDICINE VOL. 122

PLATE 68
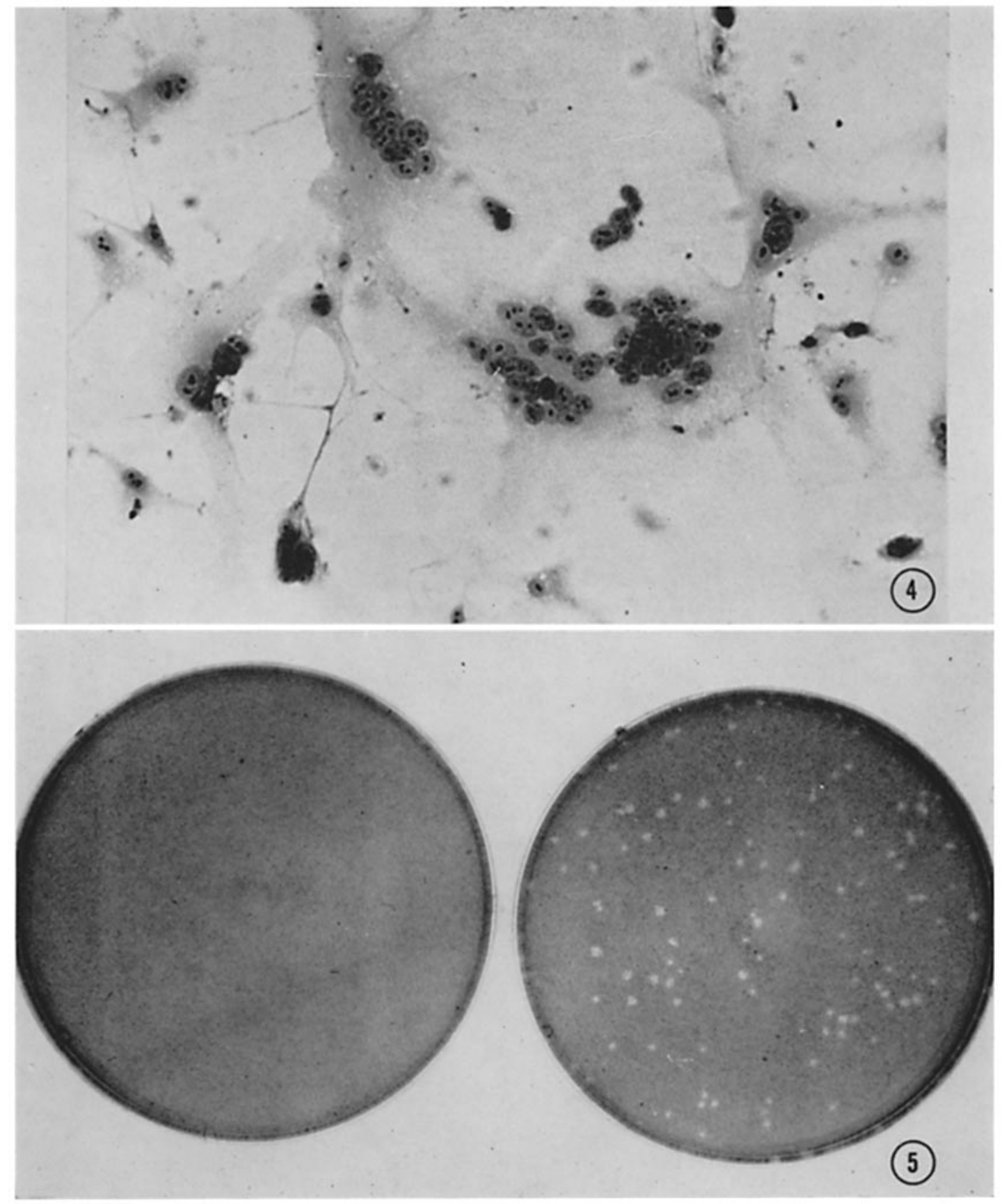

(Liebhaber et al.: Myxovirus and infectious hepatitis. I) 